\title{
Involvement of DNA methylation in tree development and micropropagation
}

\author{
Luis Valledor · Rodrigo Hasbún · Mónica Meijón · Jose Luis Rodríguez • \\ Estrella Santamaría · Marcos Viejo • Maria Berdasco · Isabel Feito · \\ Mario F. Fraga · Maria Jesús Cañal · Roberto Rodríguez
}

Received: 13 November 2006/ Accepted: 13 June 2007/Published online: 31 July 2007

(C) Springer Science+Business Media B.V. 2007

\begin{abstract}
Genes constitute only a small portion of the total genome and precisely controlling their expression represents a substantial problem for their regulation. Furthermore, non-coding DNA, that contains introns repetitive elements and active transposable elements, demands effective mechanisms to silence it long-term. Cell differentiation and development are controlled through temporal and spatial activation and silencing of specific genes. These patterns of gene expression must remain stable for many cell generations and last or change when inductive developmental signals have disappeared or new ones induce new programmes.
\end{abstract}

L. Valledor · R. Hasbún · M. Meijón ·

J. L. Rodríguez · E. Santamaría · M. Viejo ·

Maria J. Cañal · R. Rodríguez $(\square)$

Plant Physiology, Epiphysage Research Group, B.O.S.

Department, Faculty of Biology, University of Oviedo,

C/ Cat. Rodrigo Uría, s/n, Oviedo 33071, Spain

e-mail: rrodri@uniovi.es

L. Valledor · R. Hasbún · M. Meijón ·

J. L. Rodríguez · E. Santamaría · Maria

J. Cañal $\cdot$ R. Rodríguez

Asturias Institute of Biotechnology (Associated with

CSIC), Asturias, Spain

M. Meijón · I. Feito

SERIDA, Asturias Service of Agricultural Research, Ctra,

Ctra. Oviedo s/n, Villaviciosa 33300, Spain

M. Berdasco · M. F. Fraga

Cancer Epigenetics Laboratory, Molecular Pathology

Programme, National Cancer Centre (CNIO), c/ Melchor

Fernández Almagro, no 3, 28029 Madrid, Spain
What turns genes on and off? Among others, gene regulation is controlled by epigenetic mechanisms, defined as any gene-regulating activity that does not also involve changes in the DNA code and is capable of persisting. It has become apparent that epigenetic control of transcription is mediated through specific states of the chromatin structure. Associations of specific chromosomal proteins, posttranslational histone modifications and DNA methylation are some of the epigenetic mechanisms that are involved in controlling chromatin states. DNA methylation research can be approached from several standpoints, since there is a wide range of techniques available to study the occurrence and localisation of methyldeoxycytosine in the genome. Several studies dealing with DNA methylation in relation to tree development, microproprogation and somaclonal variation will be presented, with the final aim of demonstrating that DNA methylation levels are hallmarks for growing seasonal periods and are related to open windows of competence in plants.

Keywords Epigenetic - Somaclonal variation . 5-Methyl-2-deoxycytosine - Phase change · Dormancy · Ageing - In vitro tissue culture

\section{Introduction}

Unlike animals, plants cannot avoid unfavourable situations, such as climate changes or environmental 
stress like freezing, drought, or pollutants by moving over long distances to more suitable environments. So if they want to survive, they have to be able to adapt rapidly to new conditions.

Plant development is plastic and strongly influenced by biotic and abiotic factors. Hence plants require specific interaction between developmental programmes and signaling pathways triggered from external stimuli that must be coordinated at the level of chromatin organization (Reyes-Rosa and Gruissem 2002). The ontogenic development in plants is an ongoing process with unique characteristics: the theoretical maintenance of cell totipotency independently of age and organ differentiation status. If plant biotechnology is a reality, it is because plant organogenesis is reversible. Among the possible mechanisms involved in these unique cell properties, DNA methylation, included in the so-called epigenetic code, must be involved (Fraga et al. 2002a) (Fig. 1).

For many years gene activity control by DNAmethylation seemed like a plausible possibility, but lacked corroborative experimental data. In the last decade, it has become a key mechanism in the hierarchy of gene regulation and differential regulatory mechanisms (Finnegan et al. 1998). The capacity of methylation/demethylation of DNA through exogenous and endogenous factors indicates that this mechanism is involved in plant development by controlling gene expression both in vivo and in vitro (Finnegan et al. 2000).
Methylation of cytosine in the $5^{\prime}$ position of the pyrimidinic ring is the most important epigenetic alteration in eukaryotes. In animals, methyldeoxycytosine is mainly found in cytosine-guanine $(\mathrm{CpG})$ dinucleotides, whereas in plants it is more commonly located in cytosine-any base-guanine (CpNpGp) trinucleotide sequences. The presence of 5-methyldeoxycytosine $(5-\mathrm{mdC})$ in the promoter of specific genes alters the binding of transcriptional factors and other proteins to DNA in plants and animals (Finnegan et al. 2000). Thus, methylation of $\mathrm{dC}$ residues in genomic DNA plays a key role in gene expression regulation (Tariq and Paszkowski 2004).

Differential DNA methylation is not static, rather it affects meristematic cell populations and developing organs by means of stable, dynamic processes that regulate gene expression associated with the $5^{\prime}$ upstream sequence methylation status in one or both alleles. It is widely accepted that DNA methylation controls differentiation by regulating tissue-specific genes and maintaining cell status stability (Fraga et al. 2002a). Nevertheless, only limited knowledge about epigentic control during plant cell differentiation or dedifferentiation and organogenesis is available (Goodrich and Tweedie 2002). Global methylcytosine content in DNA varies widely across species, organs, and developmental states. One of the main questions regarding animal and plant development is how cells with same DNA can acquire different functions. But, how do the cells of an
Fig. 1 Relation between DNA methylation and ageing-reivigoration

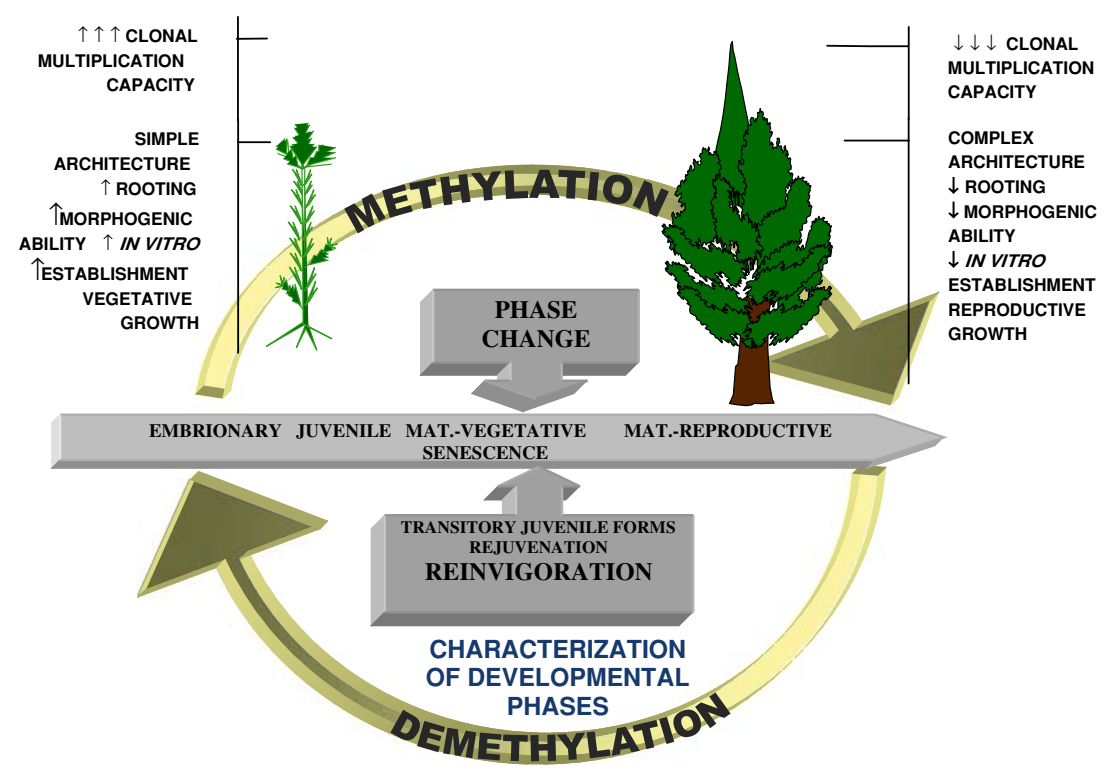


organism acquire their identity? If the organogenic processes in plants are reversible, how do cells with tissue, physiological, and ontogenic identity regain their pluripotent meristematic character?

This brief review will present our experiences dealing with DNA methylation in relation to tree development and microproprogation, with the final aim of underscoring the importance of DNA methylation plasticity in the acquisition and loss of competence both in vivo and in vitro.

\section{Functional role of DNA methylation}

DNA methylation is a dynamic mechanism by means of which plasticity is induced by environmental and/ or ontogenic signals, amongst others (Ramchandani et al. 1999). Methylation plasticity is defined as the methylation/demethylation changes which occur during plant growth and development, both in vivo and in vitro. Reductions in a given methylation level in a specific cell population or organ, called demethylation, is always present prior to the beginning of any differentiation programme, such as flowering (Zluvova et al. 2001), active growing (Steimer et al. 2004), or embryogenesis (Klimaszewska, personal communication). Differentiation implies an increase of DNA methylation, called de novo methylation. This is seen during ageing, for example along with the loss of morphogenic competence that typically occurs after long term in vitro culture (Klimaszewska, personal communication). In spite of these dynamics, some DNA methylation patterns are not erased during gametogenesis and are therefore not re-established in all generantions; hence, some kind of "epigenetic memory" exists (Saze et al. 2003).

Methylation of $\mathrm{CpG}$ islands in promoter regions or gene first exons alters the binding of transcriptional factors and other proteins, preventing RNA-Polymerase transcription of DNA and causing gene silencing. Thus, we can consider DNA methylation of these regions as an ON-OFF (unmethylated-methylated) gene regulatory mechanism (Bender 2004). Changes in gene expression caused by DNA methylation have been related to normal ontogenic development and loss-gain of morphogenic ability during ageing or reinvigoration processes; however low methylation levels cause severe phenotypic abnormalities during ontogenic development (Ronemus et al. 1996).
Furthermore, DNA methylation plays its role not only by preventing binding of transcription factors and enzymes, but it is also related to chromatin structure. DNA hypermethylation, the accumulation of methylated histone $\mathrm{H} 3$ in $\mathrm{K} 9$, and deacetylated H4 histones are characteristic of constitutive heterochromatin; while DNA hypomethylation, accumulation of methylated histone $\mathrm{H} 3$ in $\mathrm{K} 4$, and acetylation of histone $\mathrm{H} 4$ are related to euchromatin (Richards and Elgin 2002; Jenuwein and Allis 2001; Tariq and Paszkowski 2004). Chromatin compaction keeps transcriptional machinery from accessing DNA, thereby affecting gene regulation and silencing the genes in heterochromatic regions (Grant-Downtown and Dickinson 2005, 2006).

In addiction, epigenetic modifications, and in particular DNA hypomethylation, are suspected for of being responsible in part for somaclonal variation (Kaeppler et al. 2000). This variation may be seen as a point of interaction between two different phenomena: growth regulating treatments and environmental stresses (Jaligot et al. 2000). Although genetic stability is certified by conventional DNA markers, no uniform clone regenerants are often obtained. This variation could be caused by different disturbances in DNA methylation, among other mechanisms.

DNA methylation also has an important role in genetic stability, since it controls transposon and other mobile elements jumping. These elements are characterized by presenting $\mathrm{CpNpG}$ islands throughout their sequence and when unmethylated, they can jump across the genome and interrupt gene sequences rendering them silent and causing phenotypic variability (Kubis et al. 2003). It has been demonstrated that transposable elements in maize undergo cycles of activity followed by inactivity that correlate with changes in cytosine methylation (Singer et al. 2001).

\section{Biochemistry of DNA methylation}

The term DNA methylation refers to the postsynthetic methylation of deoxycytosines at the $5^{\prime}$ position of the pyrimidine ring of cytosine (the only base that can be methylated in plants) to form methyldeoxycytosine (Finnegan and Kovak 2000). Modification can occur at virtually any base, but clonal transmission of the methylation patterns only occurs at symmetrical sequences $\mathrm{CpG}, \mathrm{CpNpG}$, or $\mathrm{CpNpN}$ where $\mathrm{N}$ can be 
any deoxynucleotide. Clusters of $\mathrm{CpG}$ dinucleotides, called $\mathrm{CpG}$ islands, are often found in association with genes, most often in the promoters and first exons, but also in regions more toward the $3^{\prime}$ end (Zhang et al. 2006). In plants, DNA methylation is more common in $\mathrm{CpNpG}$ islands, characteristic of transposons, thus contributing further to the level of cytosine methylation, particularly due to the high presence of these elements in plant genomes (Kovaric et al. 1997; Rabinowicz et al. 2003).

Deoxycytosine methylation is catalyzed by a group of enzymes called methyltransferases that transfer a methyl group from S-adenosylmethionine (SAM) to the $5^{\prime}$ position of deoxycytosine. In Arabidopsis three different groups of methyltransferases have been defined: MET, responsible for maintaining methylation patterns along meiosis; CMT, unique to plants, and involved in the maintenance of methylation at $\mathrm{CpNpG}$ islands, and DRM, that participates in the establishment of new methylation patterns (Finnegan and Kovak 2000). Connections between RNA interference (RNAi) and DNA methylation (Mathieu and Bender 2004) have been recently described; for example, RNA-directed de novo methylation (RdDM) leads to methylation in a region of sequence identity between the triggering double-stranded RNA and the target DNA. This methylation pattern is maintained after elimination of trigger dsRNA in $\mathrm{CpG}$ but not in CpNpG (Jones et al. 2001).

DNA demethylation can occur passively, by replacing methylated with unmethylated cytosines during replication, and/or actively, enzymatically removing the methyl group by glycosylases. This class of activity has recently been reported by Morales-Ruiz et al. (2006) who have studied mutations in Arabidopsis DME (DEMETER eliminates $5 \mathrm{mC}$, thereby reactivating the genes) that interfere with maternal expression of imprinted genes FWA (positive regulation of flowering) and MEA (MEDEA, negatively regulates seed germination in absence of fertilization).

\section{DNA methylation study methods}

In this review, we briefly describe the methods that have been used in our research. (See Fraga and Esteller 2002, for a methodological review)
Global DNA methylation

Quantification of 5-methyldeoxycytosine genomic DNA methylation establishes certain degrees of global DNA methylation as markers for growth and developmental processes. Furthermore, from a molecular perspective, variations in global DNA methylation may mean that the chromatin structure has undergone changes during ageing.

The analysis of global DNA methylation, defined as the relation between methylated deoxycytosines and total deoxycytosines of the genome and expressed as a percentage, can be performed by HPCE (Fraga et al. 2002b) consisting of enzymatic hydrolysis of the DNA strands and phosphatase alkaline treatment, to free the deoxynucleosides, followed by a run in a HPCE system. HPCE is used to quantify and resolve peaks corresponding to each deoxynucleoside. DNA methylation percentage is calculated using the formula $[\% 5-\mathrm{mdC}=5-\mathrm{mdC}$ peak area/ $(5-$ $\mathrm{mdC}+5-\mathrm{dC}$ peak areas) $]$. This method quantifies the degree of methylation in samples starting at 2-3 $\mu \mathrm{g}$ of DNA. Similar procedures can be carried out in HPLC systems (Johnston et al. 2005), although larger run times and greater amounts of DNA are required.

Sequence-specific DNA methylation

The study of DNA methylation can also be tackled from a sequence-specific perspective. These methods are based on bisulfite modification of the DNA (Shapiro et al. 1970; Shiraishi and Hayatsu 2004), which transforms deoxycytosines into uracyl bases, while 5-methyldeoxycytosines remain unchanged. The methylation status of a given genome sequence can be analyzed by PCR amplification using specific primers designed to amplify only if deoxycytosines corresponding with primer sequences have changed (Frommer et al. 1992). Modified DNA can also be sequenced following a PCR amplification (bisulfite sequencing) in order to identify what deoxycytosines have changed (Warnecke et al. 2002). Bisulfite sequencing uses primers with no or little $\mathrm{dC}$ and makes it possible to analyze sequences of up to $400 \mathrm{bp}$. There are some other methods, like combined restriction bisulphite analysis (COBRA), which constitute a highly specific approach that lies in the creation or modification of a target for restriction endonuclease after bisulphite treatment (Xiong and 
Laird 1997) or a recently described method for rapid quantification of methylation of a specific gene that combines MS-PCR with HPCE instead of bisulphite sequencing (Yang 2006).

Tissue spatial layout of 5-mdC

The methods described provide information about methylated DNA and which genes are methylated or not. It is also necessary to know which cells contain methylated DNA, the number of cells, their location, and the evolution of the DNA methylation pattern of the tissue during ontogenic development. Histological analyses, based in DAPI staining of cell nucleus and fluorescent immunolocation of 5 -mdC can be used (Zluvova et al. 2001).

\section{DNA methylation during tree development and ageing}

Plant ontogenetic development has been studied for a long time, however very little is known about its molecular basis (Fraga et al. 2002a). Developmental transition from juvenile to either vegetative or adult phases involve changes in the pattern of cellular differentiation and organ formation.

In woody species, there is a decline in the morphogenic ability across maturation which is often a barrier for plant multiplication or regeneration (Rodríguez et al. 1998; Bonga and Aderkas 1993). Therefore, upgrading forestry programmes face the problem of selecting interesting traits during the mature stage, while vegetative propagation is only possible during the juvenile phase of development. New biotechnological alternatives are in progress to overcome this problem, albeit greater effort is needed to achieve the theoretical advantages of plant morphogenesis. The physiological status of the source of explants can have a dramatic effect on their behavior in culture (Rey et al. 1994), ageing representing the most striking.

Results obtained in our laboratory using radiata pine as a model allow us to conclude that the basal portion of the growing needles $(<1 \mathrm{~cm})$ of juvenile individuals, without reproductive ability, were characterised by a level of DNA methylation that was $42 \%$ less than the same portions of mature trees showing reproductive ability (Fraga et al. 2002c).
Results obtained with a clone that acquired its reproductive competence during the research period confirm that the increase in DNA methylation levels found among juvenile and mature states take place just after the phase change (after 5-8 years of growth) (Fraga et al. 2002a). Furthermore, in these meristematic areas, there was a gradual decrease in global DNA methylation due to repeated reinvigoration steps by serial grafting or pruning; a reduction of $35 \%$ in $5-\mathrm{mdC}$ content can be reached after fourth serial graft. This decline in the percentage of 5-mdC is directly related to the recovery of juvenile tissue morphogenic competence (Fraga et al. 2002c). Conversely, when apical portions of needles are analyzed, no differences were found on whole differentiated organs independently of the age of the donor plant. In this case, mature organs, no differences to age are detected. These results reveal the relevance of the organ to be analyzed.

Distribution patterns of 5-methylcytosine in apical and basal portions validate former results that demonstrate that the distribution of inmunofluorescence in the basal zone is dependent of ontogenic development. Results obtained by confocal immunofluorescence revealed that all nuclei stained with 5-methylcytosine antibodies were located in the peripheral cells of needles from mature vegetative branches. However, 5-methylcytosines were also located in the central axis of primordia coming from flowering branches; that is, high 5-mdC contents were found both in meristematic areas and in differentiated cells of the provascular system of mature reproductive tissues. When juvenilelike needles from epicormic shoots were analyzed, images similar to those of mature vegetative needles were obtained.

A gradual increase in DNA methylation throughout ageing was reported for other forest trees; in Castanea sativa juvenile-tree shoots have the lowest level (13.7\%), while mature-tree shoots have a DNA methylation level of $15.0 \%$. Shoots in dormancy present the highest DNA methylation level (23.0\%) independently of the donor tree age (Hasbún et al. 2005). This tendency is consistent with the phase change related to DNA methylation evolution previously reported in Pinus radiata (Fraga et al. 2002c). It must be pointed out that the use of different analytical techniques can lead to different results. In Castanea sativa, species with high concentration of polyphenols and other oxidant compounds, a new 
DNA purification method was set up to prevent these interferences. Apart from the difference between chestnut shoots and pine needles, the use of different analytical procedures might account for such different levels. It must be stated that total levels are merely indicative. This comment aside, it is clear from our results that in both angiosperms and gymnosperms, ageing is accompanied by an increase in DNA methylation and that dormancy buds contain the largest amount of methylated tissues.

These differences are noticeable enough to use as a molecular marker for ageing and chronological status. Similar studies using methylation-sensitive AFLPs instead of HPCE analysis have been conducted in Arabidopsis, revealing the same tendency. For instance, $74 \%$ of total methylation sensitive AFLPs bands in cotyledons disappeared with development (Ruíz-García et al. 2005). In summary, these data indicate that DNA methylation is not static and that it has unique dynamics during specific developmental stages.

Studies of plant growth and shoot development have identified many genes involved in meristem initiation and organ formation, whose activity is controlled by DNA methylation. Both signaling pathways, hormonal-environmental and DNA methylation interplay and regulate phase change (Genger et al. 2003; Horváth et al. 2003).

\section{Epigenetic control of flowering and phase change}

Significant progress has been made towards understanding the molecular basis of how multiple pathways regulating the floral transition are integrated. First Arabidopsis studies validated the hypothesis DNA methylation mediates the promotion of flowering by prolonged exposure to low temperatures (vernalization) (Burn et al. 1993) and described some methylation mutants and phenotypes (Vongs et al. 1993). The DNA methylation-vernalization hypothesis was tested in different vernalization-dependent late-flowering ecotypes and mutants, showing that adequate treatments with DNA demethylating agent 5 -azacytidine induced flowering significantly sooner than untreated controls (Burn et al. 1993). It was also demonstrated in Arabidopsis that the expression of MADS-box factors, e.g. flowering locus F (FLF) (flowering inhibiting factor), was inhibited by the effect of cold or by treatment with 5-azacytidine (Sheldon et al. 1999). The regulation of the FLF locus provides a plant model of how methylation systems have emerged as important control components in a major developmental change, the transition to flowering. Recent studies (Finnegan et al. 2005) on flowering locus C (FLC), another flowering inhibitor, showed that its downregulation is associated both with vernalization and low levels of DNA methylation; however this regulation occurs by means of different mechanisms, thereby breaking with the DNA methylation-vernalization hypothesis. In both cases there is a reduction of histone $\mathrm{H} 3$ trimethylated at lysine 4 and acetylation of both histones $\mathrm{H} 3$ and $\mathrm{H} 4$ around the promoter-translation start of FLC. These modifications in histone patterns were also reported to be implied in activation/inactivation of other Arabidopsis genes (Alvarez-Venegas and Avramova 2005).

In Pinus radiata, a dioecious species, it has been reported that the buds of trees that exhibit only one sex have lower DNA methylation level than juvenile buds, whereas trees that display both sexes have the highest methylation levels (Valledor 2005). Floral evocation implies epigenetic reprogramming that shifts from a vegetative to a reproductive growth pattern. Flowering genes, repressed during vegetative growth, must be expressed; hence, prior general demethylation is needed to activate some of these genes. The decrease in methylation is related to gene activation and changes in morphology pathways (Fraga et al. 2002a), as well as being connected to the process of floral induction (Burn et al. 1993; Genger et al. 2003). However, when the meristem begins to divide to form the primordia of future flower organs, DNA methylation levels rise again to permit cell differentiation and organ formation. These results have been validated in Rhododendron sp. and Castanea sativa (Meijón 2005; Hasbún et al. 2007) and are consistent with previous studies performed by Zluvova et al. (2001). In conclusion, epigenetic control, and specifically DNA methylation, plays an essential role in regulating the timing of flowering.

\section{Epigenetic control of dormancy}

Dormancy is an essential process to insure the survival of both herbaceous and woody species that 
are exposed to low winter temperatures. Bud dormancy in trees is initiated in mid-summer, long before leaf fall in the autumn. The dormant bud is an embryonic shoot consisting of a growing tip, nodes, and internodes (not yet extended), and tiny, rudimentary leaves with buds or bud primordia all encased by the bud scales that prevent desiccation, restrict the movement of oxygen, and insulate the bud from heat loss and the impact of severe, low temperatures. Growth inhibitors are known to accumulate in bud scales as well as in the leaves within the bud. Dormancy is modulated by changes in the balance of both inhibiting and stimulating endogenous substances, although the molecular basis and regulatory pathways are not fully understood.

Seed and bud dormancy has been widely studied and changes in specific gene expression have been described. In dormancy induction, both hormonal and environmental signals are the most important. These signals exert their effect through activation/inactivation of gene expression programs that dictate paradormancy, endodormancy, and ecodormancy (Anderson et al. 2001; Shimizu-Sato and Mori 2001; Rohde et al. 2002; Horvart et al. 2003; Sung and Amasino 2004).

The analysis of 5-mdC percentage in genomic DNA during chestnut seasonal development reveal that the different growth stages progress with specific variations in methylation levels (Fig. 2). Considering the annual development of the individual as a cycle of activity and dormancy, activity coincides with relatively low methylation levels, while dormancy is characterized by high levels of 5-mdC. This demonstrates the importance of DNA methylation in the developmental control of growth cycles in plants. Dormancy was also related to a reduction in transcriptome complexity in Populus tremula, as well as dormancy-specific gene induction (Schrader et al. 2004).

Seed germination requires gene expression activation. Portis et al. (2004) found that Capsicum annuum seed germination occurs with DNA demethylation. More in-depht transcriptomic studies in Arabidopsis (Nakabayashi et al. 2005) demonstrated that DNA demethylates during germination except in centromeric regions and some clusters of silences genes.

\section{Micropropagation and somaclonal variation}

Micropropagation is an important alternative to assure present and future conservation and use of valuable tree selections. However, culture conditions and material handling can provoke genetic (Phillips et al. 1994) and epigenetic (Smulders 1995; Brar and Jain 1998) variation. Although genetic markers to validate clonation are commonly used, the epigenetic status is rarely determined. Morphological alterations without genetic variations were found in both Pinus sp. emblings (Fraga et al. 2002c) and chestnut microplants (Hasbún et al. 2007), while 5-mdC varies among regenerants.

We had quantified the percentage of 5-mdC in microplants obtained via axillary bud stimulation from several clones of different ages in chestnut. Fraga et al. (2002c) demonstrated that after several in vitro subcultures (normally three) and independently of the former methylation level and age of the
Fig. 2 Methylation level in relation to season development stages

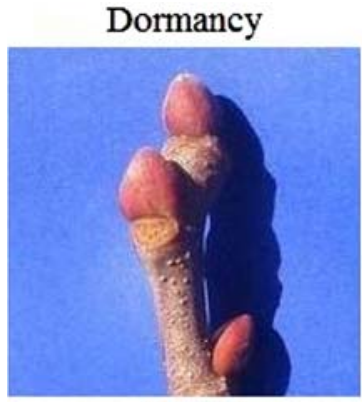

$20,2 \%$

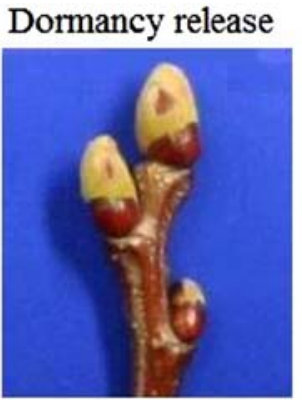

$16,0 \%$
Active growth

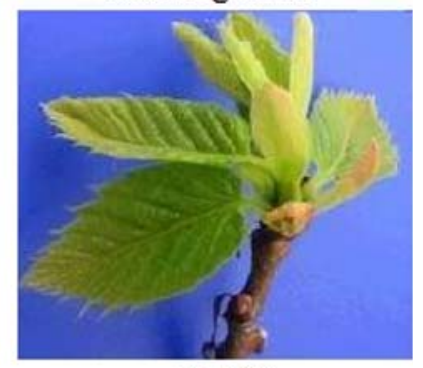

$12,0 \%$

$\%$ 5-mdC 
donor plant, all Pinus microshoots reach a certain specific level of methylation. Subsequently, when the ex vitro rooting phase is over, the striking decline in methylated cytosines highlights the elevated epigenetic plasticity of the genome in response to changes in environmental conditions, the rhizogenic process, or both.

All together, an individual constitutes a mosaic of methylation situations, and a global increase in methylation is observed with in vitro culture, characterized by parallel processes of hypomethylation, preferred by single copy sequences related to gene expression, and hypermethylation of repetitive sequences that could be related with chromosome instability or endoparasitic sequence reactivation (Kaeppler et al. 2000). In a cell and tissue culture system, differentiation and de-differentiation processes, as well as cell division are accompanied by methylation and demethylation events of tissuespecific genomic DNA (Arnholdt-Schmitt et al. 1995).

One phenomenon that has been observed by researchers culturing embriogenic tissue is the loss of the ability to produce mature somatic embryos after the tissue has been cultured for several months (Klimaszewska, personal communication; Salajova et al. 1999). The eventual loss of this potential has been associated with a change in the morphology of early somatic embryos such as short suspensors or cellular organization of the culture. Among other functions, DNA methylation may cause epigenetic changes leading to suppressed embryogenic potential.

Further evidence that gene expression is linked to embryogenesis potential came from the work of Charbit et al. (2004) who distinguished four of 28 cDNAs of Hevea brasiliensis that were differentially expressed in embryogenic and regenerating cultures versus non-embryogenic cultures. Preliminary results comparing different embryogenic and nonembryogenic lines from pinus and angiosperms consistently reveal high methylation levels for non competent lines and decreased 5-mdC in the competent ones. Hypermethylation of DNA was found to be associated with a lack of organogenic potential in radiata pine micrografts collected from mature versus juvenile trees (Fraga et al. 2002c). Cultured plant cells may undergo somaclonal variation, which may manifest as a loss of differentiation/regeneration ability.
Somaclonal variation is conceptually defined as epigenetic change that alters gene expression patterns without modifying changes in the DNA sequence (Russo et al. 1996). Somaclonal variation can be defined as the variation among clonally propagated plants of a single donor clone. Somaclonal variation can manifest as either somatically, phenotypically, or mitotically stable events, which implies stable genetic variation. Somatically stable variation includes particular phenotypes and physiologically induced variation among primary regenerants and is not often transmitted to progeny. This type of variation is particularly important in situations where the primary regenerant is the end product, as in micropropagation of forest trees. Genetic variation, heritable through meiosis, is important in situations where the end of tissue culture propagation is sold as seeds (Kaeppler et al. 2000).

Propagation-associated stress conditions often result in instability of the plant genome and breakdown of normal controls as a result of epigenetic effects due to (associated with) changes in DNA methylation (Karp 1994; Jaligot et al. 2000; Kaeppler et al. 2000). For instance, epigenetic changes in poplar cultures have previously been found to express as variable rhythms of shoot growth and dormancy, and can either be avoided or stabilized, depending on culture conditions and certain regulatory factors (Altman and Loberant 2000). Indeed, it was suggested that the plant genome is less stable than the genome of animal cells and that epigenetic changes and polysomatisms in plant tissues and organs are much more common (Phillips et al. 1994; Walbot and Cullis 1985). Moreover, and relevant to regeneration processes during vegetative propagation, epigenetic changes in plant cells are not limited to the germ line cells, but can also occur and be stabilized via meristems (Walbot and Cullis 1985). Previous studies indicate that changes in DNA methylation can occur when plants are exposed to tissue culture conditions (Phillips et al. 1994) in response to osmotic stress (Kovarik et al. 1997), and by wounding (Kaeppler and Phillips 1993). Joyce and Cassells (2002) associated different morphologies of potato microplants cultured in heterotrophic and autotrophic media with different DNA methylation levels by MSAPs analysis. Acacia mangium microshoots micropropagated in vitro with different leaf morphology, considered to be a phase change indicator, are characterized as 
having different DNA methylation levels irrespective of the age of the source material (Baurens et al. 2004).

Transposon activity within the genome is another mechanism that can interfere with gene expression and normal developmental control (Kaeppler et al. 2000; Miura et al. 2001; De Keukeleire et al. 2001). Transposon and other mobile elements jumping is repressed by the methylation of $\mathrm{CpNpG}$ islands which are distributed across its sequence. It is known that transposon expression is induced by biotical and abiotical stresses as well as to several physiological changes such as pathogen attack, environmental cues, in vitro culture, germination, interspecies introgression, or tissue irradiation (Hirochika et al. 1996; Grandbastien 1998; Kalendar et al. 2000; Maekawa et al. 2003; Liu et al. 2004; de Diego et al. 2006). Rabinowicz et al. (2003) have demonstrated that transposons are methylated in normal conditions, but a decrease in global methylation under tissue culture conditions is closely related to the expression of transposable elements, controlled by the methylation degree of its sequence (Liu et al. 2004). In plants, silent transposable elements like MULEs (Mutator Like Element) or CACTA family are methylated and can be reactivated in methylation defective mutants DDM1 (Decrease in DNA Methylation) (Miura et al. 2001; Singer et al. 2001). When transposition occurs, the inserted element can change the epigenetic status of the flanking sequences, modifying their expression or interrupting gene sequences thereby silencing them (Whitelaw and Martin 2001; Kashkush et al. 2003) which can lead to genotypic and phenotypic variation.

The application of different chemicals to growth media may also lead to the loss of gene control mechanisms, causing variation. It has been suggested that both natural and synthetic plant growth regulators control DNA methylation in the plant nucleus, although the phytohormone effect may be mediated by other proteins in nuclear extracts (Vlasova 1995).

The auxin 2,4-dichlorophenoxyacetic acid (2,4-D) has been proven to maintain undifferentiated state and habituation to in vitro culture through DNA hypermethylation (Von Aderkas and Bonga 2000; Causevic et al. 2005). Removal of 2,4-D results in reduced ethylene production, thereby increasing SAM accumulation which, in turn, results in increased DNA methylation. Therefore, at the time of 2,4-D removal (studying globular somatic embryo stage), methylation is low but increases dramatically as torpedo embryos and plantlets develop (Von Aderkas et al. 2000). On the other hand, ethylene production leads to a rapid and temporary decrease of cytosine methylation in DNA (Galaud et al. 1993a, b). Other plant growth regulators such as giberellic acid $A_{3}$, 6-benzylaminopurine and fucsicoccin have been reported to also influence DNA methylation (Vlasova et al. 1995). See Table 1 for a summary of different plant growth regulators and their effect on DNA methylation.

\section{Conclusions}

DNA methylation plasticity is a major factor involved on plant development and in vitro culture response. Demethylation normally precedes the onset of new differentiation programmes, such as sexual and asexual embryogenesis, flowering initiation, and reinvigoration. Methylation increases with age, phase change, or culture period, and is normally associated with a lack of organogenesis potential.

Methylation is stable, albeit not static, as demonstrated in several experimental situations, being the

Table 1 Effect of phytohormones on the in vitro DNA methylation

\begin{tabular}{llllll}
\hline Phytohormone & \multicolumn{5}{l}{ Relative degree (\%) of DNA methylation in the presence of phytohormone (M) } \\
\cline { 2 - 5 } & 0 & $10^{-7}$ & $10^{-6}$ & $10^{-5}$ & $10^{-4}$ \\
\hline $\mathrm{GA}_{3}{ }^{\mathrm{a}}$ & 100 & 116 & 165 & 146 & 124 \\
$6-\mathrm{BAP}$ & 106 & 134 & 130 & 124 \\
Fusicoccin $^{\mathrm{a}}$ & 100 & 126 & 133 & 120 & 103 \\
$2,4-\mathrm{D}^{\mathrm{b}}$ & 100 & - & - & - & 140 \\
\hline
\end{tabular}

${ }^{\mathrm{a}}$ Wheat seedlings (Vlasova et al. 1995) and ${ }^{\mathrm{b}}$ sugarbeet cell lines (Causevic et al. 2005) 
basis of cellular plasticity. Methylation/demethylation control will enable us to manage cell growth and functions, with the possibility of directing cell mechanism to applied functionalities.

Acknowledgements The financial support needed to guarantee our progress into the insight of ageing, phasechange, and reinvigoration, as well as the progress being made in the research for quality markers has come from EU Projects FAIR3-CT96-1445, INCO 10063, and MCT-AGL2000-2126, AGL 2004-00810 Spanish National Projects. The Spanish M.E.C.D. supported fellowships of all young researchers. We would also like to thank Ms. Priscilla Chase for her linguistic revision of the text.

\section{References}

Altman A, Loberant B (2000) Micropropagation of plants: principles and practices. In: $\mathrm{Tj} \mathrm{R}$ (ed) Encyclopedia of Cell Technology, vol 1. John Wiley \& Sons, Inc., New York, pp 916-929

Alvarez-Venegas R, Avramova Z (2005) Methylation patterns of histone H3 Lys 4, Lys 9 and Lys 27 in transcriptionally active and inactive Arabidopsis genes and in atx 1 mutants. NAR 33:5199-5207

Anderson J, Chao W, Horvath D. (2001) A current review on the regulation of dormancy in vegetative buds. Weed Sci 49:581-589

Arnholdt-Schmitt B, Herterich S, Neumann K (1995) Physiological aspects of genome variavility in tissue culture. I. growth phase-dependent differential DNA methylation of the carrot genome (Daucus carota L.) during primary culture. TAG 91:809-815

Baurens FC, Nicolleau J, Legavre T, Verdeil JL, Monteuuis O (2004) Genomic DNA methylation of juvenile and mature Acacia mangium micropropagated in vitro with reference to leaf morphology as a phase change marker. Tree Physiol 24:401-407

Bender J (2004) DNA methylation and epigenetics. Ann Rev Plant Biol 55:31-68

Bonga JM, von Aderkas P (1993) Rejuvenation of tissues from mature conifers and its implications for propagation in vitro. In: Ahuja MR, Libby WJ (eds) Clonal forestry I, genetics and biotechnology. Springer-Verlag, Berlin, Heidelberg, pp 182-199

Brar DS, Jain SM (1998) Somaclonal variation: mechanisms and applications in crop improvement. In: Jain SM, Brar DS, Ahloowalia BS (eds) Somaclonal variation and induced mutations in crop improvement. Kluwer Academic Publishers, Boston, USA, pp17-37

Burn JE, Bagnall DJ, Metzger JD, Dennis ES, Peacock WJ (1993) DNA methylation, vernalization and the initiation of flowering. PNAS 90(1):287-291

Causevic A, Delaunay A, Ounnar S, Righezza M, Delmotte F, Brignolas F, Hagège D, Maury S (2005) DNA methylation and demethylating treatments modify phenotype and cell wall differentiation state in sugarbeet cell lines. Plant Physiol Biochem 43:681-691
Charbit E, Legavre T, Lardet L, Bourgeois E, Ferrière N, Carron MP (2004) Identification of differentially expressed cDNA sequences and histological characteristics of Hevea brasiliensis calli in relation to their embryogenic and regenerative capacities. Plant Cell Rep 22:539-548

de Diego JG, Rodríguez FD, Rodríguez Lorenzo JL, Cervantes E, Grappin P (2006) cDNA-AFLP analysis of seed germination in Arabidopsis thaliana identifies transposons and new genomic sequences . J Plant Physiol 163:452462

de Keukeleire P, Maes T, Sauer M, Zethof J, Van Montagu M, Gerats T (2001) Analysis by Transposon Display of the behavior of the dTph1 element family during ontogeny and inbreeding of Petunia hybrida. Mol Genet Genomics 265:72-81

Finnegan EJ, Genger RK, Peacock WJ, Dennis ES (1998) DNA methylation in plants. Annu Rev Plant Physiol Plant Mol Biol 49:223-247

Finnegan EJ, Kovak KA (2000) Plant DNA methyltransferases. Plant Mol Biol 43:189-201

Finnegan J, Kovak KA, Jaligot E, Sheldon CC, Peacock WJ, Dennis ES (2005) The downregulation of Flowering Locus C (FLC) expression in plants with low levels of DNA methylation and by vernalization occurs by distinct mechanisms. Plant J 44(20):420-432

Finnegan EJ, Peacock WJ, Dennis ES (2000) DNA methylation, a key regulator of plant development and other processes. Curr Opin Gen Dev 10:217-223

Fraga M, Cañal M, Rodriguez R (2002a) Phase-change related epigenetic and physiological changes in Pinus radiata D. Don Planta 215:672-678

Fraga MF, Esteller M (2002) DNA Methylation: A profile of methods and applications. BioTechniques 33(3):632649

Fraga MF, Rodriguez R, Cañal MJ (2002c) Genomic DNA methylation-demethylation during aging and reinvigoration of Pinus radiata. Tree Physiol 22:813-816

Fraga MF, Uriol E, Diego LB, Berdasco M, Esteller M, Cañal MJ, Rodríguez R (2002b) High-performance capillary electrophoretic method for the quantification of 5-methyl $2^{\prime}$-deoxycytidine in genomic DNA: Application to plant, animal and human cancer tissues. Electrophoresis 23:1677-1681

Frommer M, McDonald LE, Millar DS, Collis CM, Watt F, Grigg GW, Molloy PL, Paul CL (1992) A genomic sequencing protocol that yields a positive display of 5-methylcytosine residues in individual DNA strands. PNAS 89:1827-1831

Galaud JP, Gaspa T, Boyer N (1993a) Effect of anti-DNA methylation drugs on growth, level of methylated DNA, peroxidase activity and ethylene production of Bryonia dioica internodes. Physiologia plantarum 87:528-534

Galaud JP, Gaspa T, Boyer N (1993b) Inhibition of internode growth due to mechanical stress in Bryonia dioica: relationship between changes in DNA methylation and ethylene metabolism. Physiologia plantarum 87:25-30

Gerger RK, Peacock WJ, Dennis ES, Finnegan EJ (2003) Opposing effects of reduced DNA methylation on flowering time in Arabidopsis thaliana. Planta 2003(3): $461-466$ 
Goodrich J, Tweedie S (2002) Remembrance of things past: Chromatin remodelling in plan development. Ann Rev Cell Dev Biol 18:707-746

Grandbastien M (1998) Activation of plant retrotransposons under stress conditions. Trends Plant Sci Rev 3:181-187

Grant-Downton RT, Dickinson HG (2005) Epigenetics and its implications for plant biology. 1. The epigenetic network in plants. Ann Bot 96:1143-1164

Grant-Downton RT, Dickinson HG (2006) Epigenetics and its implications for plant biology 2. The 'epigenetic epiphany': epigenetics, evolution and beyond. Ann Bot 97:11-27

Hasbún R, Valledor L, Berdasco M, Santamaría E, Cañal MJ, Rodríguez R, Rios D, Sánchez M (2005) In vitro proliferation and Genome DNA methylation in adult chesnuts. Act Hort 693:333-339

Hasbún R, Valledor L, Berdasco M, Santamaría E, Cañal MJ, Rodríguez R, (2007) Dynamics of DNA methylation during chestnut trees development, Application to breeding programs. Act Hort (in press)

Hirochika H, Sugimoto K, Otsuki Y, Tsugawa H, Kanda M (1996) Retrotransposons of rice involved in mutations induced by tissue culture. PNAS 93:7783-7788

Horvath D, Chao W, Anderson J, Foley M. (2003) Knowing when to grow: signal transduction processes regulating dormancy in vegetative buds. Trends Plant Sci 8:534-540

Jaligot E, Rival A, Beulé T, Dussert S, Verdeil JL (2000) Somaclonal variation in oil palm (Elaeis guineensis Jacq.): the DNA methylation hypothesis. Plant Cell Rep 19:684-690

Jenuwein T, Allis CD (2001) Translating the Histone code. Science 293:1074-1080

Johnston JW, Harding K, Bremner DH, Souch G, Green J, Lynch PT, Grout B, Benson EE (2005) HPLC analysis of plant DNA methylation: a study of critical methodological factors. Plant Physiol Biochem 43:844-853

Jones L, Ratcliff F, Baulcombe DC (2001) RNA-directed transcriptional gene silencing in plants can be inherited independently of the RNA trigger and requires Met1 for maintenance. Curr Biol 11:747-757

Joyce SM, Cassells AC (2002) Variation in potato microplant morphology in vitro and DNA methylation. Plant Cell Tissue Organ Cult 70:125-137

Kaeppler SM, Kaeppler HF, Rhee Y (2000) Epigenetic aspects of somaclonal variation in plants. Plant Mol Biol 43:179-188

Kaeppler SM, Phillips RL (1993) Tissue culture-induced DNA methylation variation in maize. PNAS 90:8773-8776

Kalendar R, Tanskanen J, Immonen S, Nevo E, Schulman AH (2000) Genome evolution in wild barley (Hordeum spontaneum) by BARE-1 retrotransposon dynamics in response to sharp microclimatic divergence. PNAS 97:6603-6607

Karp A (1994) Origins, causes, and uses of variation in plant tissue cultures. In: Vasil IK, Thorpe TA (eds) Plant cell and tissue culture. Kluwer Academic Publishers, Dordrecht, The Netherlands, pp 139-151

Kashkush K, Feldman M, Levy AA (2003) Transcriptional activation of retrotransposons alters the expression of adjacent genes in wheat. Nat Genet 33:102-106

Kovarik A, Matyásek R, Leitch B, Gazdová B, Fulnecek J, Bezdek M (1997) Variability in CpNpG methylation in higher plant genomes. Gene 204:308-315
Kubis SE, Castilho AMF, Vershinin AV, Heslop-Harrison JS (2003) Retroelements, transposons and methylation status in the genome of oil palm (Elaeis guineensis) and the relationship to somaclonal variation. Plant Mol Biol 52:69-79

Liu ZL, Han FP, Tan M, Shan XH, Dong YZ, Wang XZ, Fedak GS, Hao·Bao L (2004) Activation of a rice endogenous retrotransposon Tos 17 in tissue culture is accompanied by cytosine demethylation and causes heritable alteration in methylation pattern of flanking genomic regions. TAG 109:200-209

Maekawa M, Hase Y, Shikazono N, Tanaka A (2003) Induction of somatic instability in stable yellow leaf Mutant of rice by ion beam irradiation. Nucl Instr and Meth in Phys Res B 206:579-585

Mathieu O, Bender J (2004) RNA-directed DNA methylation. J Cell Sci 117:4881-4888

Meijón M (2005) Desarrollo vegetativo y floral en azalea. Marcadores moleculares y fisiológicos de calidad de planta. Dissertation, University of Oviedo

Miura A, Yonebayashi S, Watanabe K, Toyama T, Shimada H, Kakutani T (2001) Mobilization of transposons by a mutation Abolishing full DNA methylation in Arabidopsis. Nature 411:212-214

Morales-Ruiz T, Ortega-Galisteo AP, Ponferrada-Marín MI, Martínez-Macias MI, Ariza RR, Roldán Arjona T (2006) Demeter and Repressor Of Silencing 1 encode 5-methylcytosine-DNA glycosylases. PNAS 103:6853-6858

Nakabayashi K, Okamoto M, Koshiba T,Kamiya Y,Nambara E (2005) Genome-wide profiling of stored mRNA in Arabidopsis thaliana seed germination: epigenetic and genetic regulation of transcription in seed. Plant $\mathbf{J}$ 41(5):697-709

Phillips RL, Kaeppler SM, Olhoft P (1994) Genetic instability of plant tissue cultures: breakdown of normal controls. PNAS 91:5222-5226

Portis E, Acquadro A, Lanteri S (2004) Analysis of DNA methylation during germination of pepper (Capsicum annuит L.) seeds using methylation-sensitive amplification polymorphism (MSAP). Plant Sci 166(1):169-178

Rabinowicz PD, Palmer LE, May BP, Hemann MT, Lowe SW, McCombie WR, Martienssen RA (2003) Genes and transposons are differentially methylated in pants, but not in mammals. Genome Res 13:2658-2664

Ramchandani S, Bhattacharya SK, Cervoni M, Szyf M (1999) DNA methylation is a reversible biological signal. PNAS 96:6107-6112

Rey M, Diaz-Sala C, Rodríguez R (1994) Effect of repeated severe pruning on endogenous polyamine content in hazelnut trees. Physiologia Plantarum 92(3):487-492

Reyes Rosa JC, Gruissem HW (2002) Chromatin-Remodeling and Memory Factors. New Regulators of Plant Development. Plant Physiol 130(3):1090-1101

Richards EJ, Elgin SC (2002) Epigenetic codes for heterochromatin formation and silencing: rounding up the usual suspects. Cell 108:489-500

Rodríguez R, Fraga MF, Pacheco J, Cañal MJ (1998) Envejecimiento vegetal. Una barrera a la propagación vegetativa. Alternativas In: Ríos DG, Olate MS (eds)

Rohde A, Prensen E, De Rycke R, Engler G, Van Montagu M, Boerjan W (2002) PtABI3 impinges on the growth and 
differentiation of embryonic leaves during bud set in poplar. Plant Cell 14:1885-1901

Ronemus MJ, Galbiati M, Ticknor C, Chen J, Dellaporta SL (1996) Demethylation-induced developmental pleiotropy in Arabidopsis. Science 273:654-657

Ruiz-García L, Cervera M, Martínez-Zapater J (2005) DNA methylation increases throughout Arabidopsis development. Planta 222:201-206

Russo VEA, Martienssen RA, Riggs AD (1996) Epigenetic mechanisms of gene regulation. Cold Spring Harbor Laboratory Press, Cold Spring Harbor, NY

Salajova T, Salaj J, Kormutak A, (1999) Initiation of embryogenic tissues and plantlet regeneration from somatic embryos of Pinus nigra Arn. Plant Sci 145:33-40

Saze H, Scheid OM, Paszkowski J (2003) Maintenance of CpG methylation is essential for epigenetic inheritance during plant gametogenesis. Nat Gen 34:65-69

Schrader J, Moyle R, Bhalerao R, Hertzberg M, Lundeberg J, Nilsson P, Bhalerao R (2004) Cambial meristem dormancy in trees involves extensive remodelling of the transcriptome. Plant J 40:173-187

Shapiro R, Servis RE, Welcher M (1970) Reactions of uracil and cytosine derivatives with sodium bisulfite:a specific deamination method. J Am Chem Soc 92:422-424

Sheldon CC, Burn JE, Perez PP, Metzger J, Edwards A, Peacock WJ, Dennis ES (1999) The FLF Mads Box gene: a repressor of flowering in Arabidopsis regulated by vernalization and methylation. Plant Cell 11:445-458

Shimizu-Sato S, Mori H (2001) Control of outgrowth and dormancy in axillary buds. Plant Physiol 127:1405-1413

Shiraishi M, Hayatsu H (2004) High-speed conversion of cytosine to uracil in bisulfite genomic sequencing analysis of dna methylation. DNA Res 11:409-415

Singer T, Yordan C, Martienssen RA (2001) Robertson's mutator transposons in A. thaliana are regulated by the chromatin-re-modelling gene Decrease in DNA Methylation (DDM1). Genes Dev 15:591-602

Smulders MJM, Rus-Kortekaas W, Vosman B (1995) Tissue culture-induced DNA methylation polymorphisms in repetitive DNA of tomato calli and regenerated plants. TAG 91:1257-1264

Steimer A, Schob H, Grossniklaus U (2004) Epigenetic control of plant development: new layers of complexity. Curr Opin Plant Biol 7:11-19
Sung S, Amasino R (2004) Vernalization and epigenetics: how plants remember winter. Curr Opin Plant Biol 7:4-10

Tariq M, Paszkowski J (2004) DNA and histone methylation in plants. Trends Genet 20:244-251

Valledor L (2005) Monitorización epigenética de la producción comercial de cuatro clones de Pinus radiata D. Don mediante estaquillado y macroinjerto. Dissertation, University of Oviedo

Vlasova TI, Demidenko ZN, Kirnos MD, Vanyushin BF (1995) In vitro DNA methylation by wheat nuclear cytosine DNA methytransferase: effect of phytohormones. Gene 157:279-281

von Aderkas P, Bonga J (2000) Influencing micropropagation and somatic embrygenesis in mature trees by manipulation of phase change, stress and culture environment. Tree Physiol 20:921-928

Vongs A, Kakutani T, Martienssen RA, Richards EJ (1993) Arabidopsis thaliana DNA methylation mutants. Science 260:1926-1928

Walbot V, Cullis CA (1985) Rapid genomic change in higher plants. Annu Rev Plant Physiol 36:367-396

Warnecke PM, Stirzaker C, Song J, Grunau C, Melki JR, Clarka SJ (2002) Identification and resolution of artifacts in bisulfite sequencing. Methods 27:101-107

Whitelaw E, Martin DIK (2001) Retrotransposons as epigenetic mediators of phenotypic variation in mammals. Nat Genet 27:361-365

Xiong Z, Laird PW (1997) COBRA: a sensitive and quantitative DNA methylation assay. Nucleic Acids Res 25:25322534

Yang I, Park IY, Jang S-M, Shi LH, Ku H-K, Park S-R (2006) Rapid quantification of DNA methylation through dNMP analysis following bisulfite-PCR. Nucl Acids Res 34(e61):61-69

Zhang X, Yazaki J, Sundaresan A, Cokus S, Chan SW-L, Chen H, Henderson IR, Shinn P, Pellegrini M, Jacobsen SE, Ecker JR (2006) Genome-wide high-resolution mapping and functional analysis of DNA methylation in Arabidopsis. Cell 126:1189-1201

Zluvova J, Janousek B, Vyskot B (2001) Immunohistochemical study of DNA methylation dynamics during plant development. J Exp Bot 52:2265-2273 